\title{
Food applications of natural antimicrobial compounds
}

\author{
Annalisa Lucera, Cristina Costa, Amalia Conte and Matteo A. Del Nobile* \\ Lab of Food Processing and Packaging, Department of Food Science, Agricultural Faculty, University of Foggia, Foggia, Italy
}

Edited by:

Mirian A. F. Hayashi, Universidade

Federal de São Paulo, Brazil

Reviewed by:

Rikke L. Meyer, Aarhus University,

Denmark

Dmitri Debabov, NovaBay

Pharmaceuticals, USA

Antonio Bevilacqua, University of

Foggia, Italy

${ }^{*}$ Correspondence:

Matteo A. Del Nobile, Lab of Food

Processing and Packaging,

Department of Food Science,

Agricultural Faculty, University of

Foggia, Via Napoli 25, 71122 Foggia,

Italy.

e-mail:ma.delnobile@unifg.it
In agreement with the current trend of giving value to natural and renewable resources, the use of natural antimicrobial compounds, particularly in food and biomedical applications, becomes very frequent. The direct addition of natural compounds to food is the most common method of application, even if numerous efforts have been made to find alternative solutions to the aim of avoiding undesirable inactivation. Dipping, spraying, and coating treatment of food with active solutions are currently applied to product prior to packaging as valid options. The aim of the current work is to give an overview on the use of natural compounds in food sector. In particular, the review will gather numerous case-studies of meat, fish, dairy products, minimally processed fruit and vegetables, and cereal-based products where these compounds found application.

\section{Keywords: antimicrobial compounds, food preservation, natural compounds, essential oils, shelf-life extension}

\section{INTRODUCTION}

Many food products are perishable by nature and require protection from spoilage during their preparation, storage, and distribution to give them desired shelf life. The demand for minimally processed, easily prepared, and ready-to-eat fresh food products, globalization of food trade, and distribution from centralized processing pose major challenges for food safety and quality. Food products can be subjected to contamination by bacteria and fungi. Many of these microorganisms can cause undesirable reactions that deteriorate flavor, odor, color, sensory, and textural properties of foods. Microbial growth is a major concern because some microorganisms can potentially cause food-borne illness. In packaged foods, growth and survival of common spoilage and pathogenic microorganisms such as Listeria monocytogenes, Escherichia coli O157, Salmonella, Staphylococcus aureus, Bacillus cereus, Campylobacter, Clostridium perfringens, Aspergillus niger, and Saccharomyces cerevisiae are affected by a variety of intrinsic factors, such as $\mathrm{pH}$ and presence of oxygen or by extrinsic factors associated with storage conditions, including temperature, time, and relative humidity (Singh et al., 2003; Lòpez-Malo et al., 2005; Rydlo et al., 2006).

To prevent growth of spoilage and pathogenic microorganisms in foods, several preservation techniques, such as heat treatment, salting, acidification, and drying have been used in the food industry (Davidson and Taylor, 2007; Farkas, 2007). Numerous efforts are conducted to find natural alternatives to prevent bacterial and fungal growth in foods. In recent years, because of the great consumer awareness and concern regarding synthetic chemical additives, foods preserved with natural additives have become very popular. To inhibit growth of undesirable microorganisms in food, the antimicrobials can be directly added into the product formulation, coated on its surface or incorporated into the packaging material. Direct incorporation of active agents into food results in an immediate but short-term reduction of bacterial populations, while the antimicrobial films can maintain their activity for a long period of time (Appendini and Hotchkiss, 2002; Hanušová et al., 2009).

Main natural compounds are essential oils derived from plants (e.g., basil, thyme, oregano, cinnamon, clove, and rosemary), enzymes obtained from animal sources (e.g., lysozyme, lactoferrin), bacteriocins from microbial sources (nisin, natamycin), organic acids (e.g., sorbic, propionic, citric acid) and naturally occurring polymers (chitosan). In this context, plant essential oils are gaining a wide interest in food industry for their potential as decontaminating agents, as they are Generally Recognized as Safe (GRAS). The active components are commonly found in the essential oil fractions and it is well established that most of them have a wide spectrum of antimicrobial activity, against food-borne pathogens and spoilage bacteria (Gutierrez et al., $2008,2009)$. The antimicrobial activity of plant essential oils is due to their chemical structure, in particular to the presence of hydrophilic functional groups, such as hydroxyl groups of phenolic components and/or lipophilicity of some essential oil components (Dorman and Deans, 2000). Usually, the compounds with phenolic groups as oils of clove, oregano, rosemary, thyme, sage, and vanillin are the most effective (Skandamis et al., 2002). They are more inhibitory against Gram-positive than Gram-negative bacteria (Mangena and Muyima, 1999; Marino et al., 2001).

Allyl-isothiocyanate is the major antimicrobial component of mustard and horseradish oil. It has been found to be more effective against Gram-negative bacteria with less or no effect on lactic acid bacteria. Although its antimicrobial activity varies widely (Delaquis and Mazza, 1995), the volatile compound particularly inhibits E. coli (Nadarajah et al., 2002; Muthukumarasamy et al., 2003).

The use of bacteriocin-producing lactic acid bacteria or their more or less purified bacteriocins has been also receiving increased interest. Bacteriocins are small bacterial peptides that show strong antimicrobial activity against closely related bacteria. Nisin is a polypeptide produced by Lactococcus lactis spp. It has 
been approved as a food additive with GRAS status in over 50 countries worldwide. It has a relatively broad spectrum of activity against various lactic acid bacteria and other Gram-positive bacteria. Moreover, it is particularly effective against heat-resistant bacterial spores of Clostridium botulinum and against food-borne pathogens such as L. mococytogenes, S. aureus, or B. cereus (Brewer et al., 2002; Lopez-Pedemonte et al., 2003; Sobrino-Lopez and Martin-Belloso, 2006). Use of nisin in conjunction with ethylenediamine tetra-acetic acid (EDTA) may increase the effectiveness. Moreover, the effect of nisin can be enhanced by using exposure to chelating agents, sub-lethal heat, osmotic shock and freezing, because these treatments make the cell wall of Gram-negative microorganisms more permeable and therefore more susceptible to the nisin (Gálvez et al., 2007).

The enzymes represent another group of natural compounds that found application in food as valid preservatives. Lysozyme for example, is a lytic enzyme found in foods, such as milk and eggs, which can hydrolyze $\beta-1,4$ linkages between $\mathrm{N}$-acetylmuramic acid and $\mathrm{N}$-acetylglucosamin (Cunningham et al., 1991). Commercially, lysozyme has been used primarily to prevent late blowing in semi-hard cheeses, caused by Clostridium tyrobutyricum. It is well known that lysozyme is bactericidal against Gram-positive bacteria, whereas it is essentially ineffective against Gram-negative bacteria, owing to the presence of a lipopolysaccharide layer in the outer membrane. It has been recognized since the 1960's that susceptibility of Gram negative bacteria to lysis by lysozyme can be increased by the use of membrane disrupting agents, such as detergents and chelators (EDTA) (Vaara, 1992; Shelef and Seiter, 1993; Branen and Davidson, 2004).

Organic acids and their salts are widely used as chemical antimicrobial agents because their efficacy is generally well understood and cost effective. The most effective organic compounds are acetic, lactic, propionic, sorbic, and benzoic acid. Their antimicrobial effect is based on the increase in proton concentration thereby lowering the external $\mathrm{pH}$. Organic acids may affect the integrity of microbial cell membrane or cell macromolecules or interfere with nutrient transport and energy metabolism, causing bactericidal effect (Ricke, 2003). Production of organic acids had been possible before the discovery of microorganisms, with lactic acid first being commercially produced by fermentation in 1880 , but the majority of the organic acids produced were being chemically extracted or synthesized from other chemicals. Mixtures of acids could exert a wider antimicrobial activity than a single organic acid (Theron et al., 2010).

Among the natural antimicrobials, chitosan also received considerable interest for commercial applications. It has been used in medical, food, agricultural, and chemical industry, mainly due to its high biodegradability and antimicrobial properties. The biological activity of chitosan depends on its molecular weight, degree of deacetylation and derivatisation, such as degree of substitution, length, and position of a substitute in glucosamine units of chitosan, $\mathrm{pH}$ of chitosan solution and the target organisms (No et al., 2007). It is commercially produced from crab and shrimp shell wastes, with different deacetylation grades and molecular weights and, hence, it possess different functional properties, like emulsification ability, dye binding, and gelation.
Chitosan has also been documented to possess a film-forming property for use as edible film or coating, to decrease water vapor and oxygen transmission, diminish respiration rate and increase shelf life of fruit (Jiang and Li, 2001).

This review focuses on the use of natural compounds to control microbiological and physicochemical shelf life of main food categories, such as meat, fish, dairy products, minimally processed fruit and vegetables and cereal-based goods. The information is mostly based on case-studies dealing with application of active compounds to prevent microbial proliferation occurring in packaged food during storage.

\section{MINIMALLY PROCESSED FOOD AND VEGETABLES JUICES}

Minimally processed products are one of the major growing segments in food retail establishments. However, fresh-cut fruit and vegetables are widely studied because of the difficulties in preserving their fresh-like quality during prolonged periods. The goal of fresh-cut products is to deliver convenience and high quality. Taking into account the pressure of consumers about the use of synthetic chemicals, natural compounds have been suggested as a valid preservation technique (Table 1). Dipping, impregnation, coating, and spraying are the different ways of applications of active agents to fresh-cut fruit and vegetables but among them, the most recent results on the application of active compounds to ready-to-eat fruit and vegetables deal with coating systems. In the follow, some relevant examples are reported.

Malic acid in combination with various stabilizing compounds was used by Raybaudi-Massilia et al. (2009) for fresh-cut apples. As reported by Bico et al. (2009), the combined effect of chemical dip and/or edible coating and/or controlled atmosphere (CA) on quality of fresh-cut banana was investigated. Banana slices were dipped into a solution containing $1 \%(\mathrm{w} / \mathrm{v})$ calcium chloride, $0.75 \%(\mathrm{w} / \mathrm{v})$ ascorbic acid, and $0.75 \%(\mathrm{w} / \mathrm{v})$ cysteine and/or combined with a carrageenan coating and/or combined with CA $\left(3 \% \mathrm{O}_{2}+10 \% \mathrm{CO}_{2}\right)$. Dipping combined with CA treatment prevented product weight loss and increased polyphenol oxidase activity; regarding microbiological quality, the combined strategies prevented microbial growth after 5 days of storage at $5^{\circ} \mathrm{C}$. The antimicrobial effects of propionic, acetic, lactic, malic, and citric acid against E. coli O157:H7, S. Typhimurium, and L. monocytogenes on whole red organic apples and lettuce were also clearly demonstrated by Park et al. (2011).

Raybaudi-Massilia et al. (2008) investigated the combined effects of malic acid and essential oils of cinnamon, palmarosa, and lemongrass $(0.3$ and $0.7 \%)$ and their main active compounds (eugenol, geraniol, and citral, $0.5 \%$ ) on microbiological and physicochemical shelf-life of fresh-cut "Piel de Sapo" melon (Cucumis melo L.). The active compounds were incorporated into an alginate-based edible coating. Melon pieces were inoculated with a $S$. Enteritidis $\left(10^{8} \mathrm{CFU} / \mathrm{ml}\right)$ culture before applying the coating. The incorporation of essential oils or their active compounds into the edible coating prolonged the microbiological shelf-life by more than 21 days. Pure citral and citron essential oil were added in the syrup of industrial ready-to-eat fruit salads stored at $9^{\circ} \mathrm{C}$. Both citral $(25-125 \mathrm{ppm})$ and citron essential oil $(300,600,900 \mathrm{ppm})$ were able to prolong the microbial 
Table 1 | Relevant examples of natural active agents applied to minimally processed products.

\begin{tabular}{ll}
\hline $\begin{array}{l}\text { Products and storage } \\
\text { conditions }\end{array}$ & Natural compounds \\
\hline Fresh-cut papaya stored in & $\begin{array}{l}\text { A microencapsulated beta-cyclodextrin } \\
\text { and trans-cinnamaldehyde complex } \\
\text { trays at } 4^{\circ} \mathrm{C}\end{array}$ \\
$\begin{array}{l}(2 \mathrm{~g} / 100 \mathrm{~g}) \text { incorporated into a } \\
\text { multilayered edible coating made of } \\
\text { chitosan and pectin }\end{array}$
\end{tabular}

Cabbage packaged under vacuum, air and two MAP

Minimally processed broccoli packaged in multilayered polyolefin bags and stored at $5^{\circ} \mathrm{C}$ for 18 days

Ready-to-eat lettuce and carrots packaged in oriented polypropylene bags and $\left(100 \% \mathrm{~N}_{2}\right.$ and $100 \% \mathrm{CO}_{2}$ ) stored at $4^{\circ} \mathrm{C}$
Dipping treatment with acetic, lactic, and malic acids (1\% and $2 \%$ )

Edible coating based on chitosan and carboxymethyl-cellulose

\section{Dipping treatment with oregano and thyme}

Solution of $1 \%$ chitosan

Coating containing 5,10 , and $20 \mathrm{~g}$ of chitosan/L

\section{Main results}

References

The coating improved the microbiological and physicochemical quality of fresh-cut papaya. It extended the shelf-life up to 15 days compared to the control ( $<7$ days)

Some pathogens inoculated on cabbage were significantly reduced by treatment with $2 \%$ acetic, $1 \%$ lactic, and $2 \%$ malic acids

The coatings retard product weight loss, browning, and yellowing, reduced stem hardening, microbial growth, and improved total chlorophyll and ascorbic acid retention

The solution containing oregano recorded a significantly lower initial total viable count level than the water treatment on carrots. The sensory panel found essential oil treatments acceptable for carrots throughout storage, but no for lettuce rejected for overall appreciation by day 7

The chitosan coating inhibited growth of microorganisms and significantly affected the microbiological stability of the strawberries, above all when the samples were packaged under active MAP

$30 \% \mathrm{CO}_{2}, 5 \% \mathrm{O}_{2}$ )

percentage of oxygen

Fresh-cut mushrooms packed in polyethylene bags and then stored at $4^{\circ} \mathrm{C}$
At $4^{\circ} \mathrm{C}$ for 15 days, $20 \mathrm{~g} / \mathrm{L}$ chitosan coating inhibited growth of total bacteria, yeasts, and moulds
Brasil et al., 2012

Bae et al., 2011

Ansorena et al., 2011

Gutierrez et al., 2009

Campaniello et al., 2008

Hesham, 2008 shelf-life. Citron essential oil doubled the time needed for the wild microflora to reach concentrations able to produce a perceivable spoilage in condition of thermal abuse $\left(9^{\circ} \mathrm{C}\right)$. The same essential oil showed a strong inhibition against L. monocytogenes, but exerted limited effects on the survival of $S$. Enteritidis and E. coli (Belletti et al., 2008). Generally, when applying bioactive coatings containing essential oils to fruits and vegetables, one of the limiting factors is the impact of such components on the sensory characteristics of the coated products, mainly due to the great amount of volatile compounds which mask the natural flavor of fruits and vegetables. The use of compatible essential oil-foodstuff could also be a good alternative.

Natural volatile compounds such as methyl jasmonate, ethanol, tea tree oil, and garlic oil were applied on fresh-cut tomato stored at $5^{\circ} \mathrm{C}$ for 15 days. Ethanol combined with methyl jasmonate was more effective in suppressing microbial proliferation than each single compound. In addition, this combination preserved firmness and color better than the other antimicrobial preservatives. Moreover, methyl jasmonate let keep higher content of lycopene, ascorbic acid and phenolic compounds (Ayala-Zavala et al., 2008). Rojas-Graü et al. (2007) investigated the effect of lemongrass, oregano oil, and vanillin incorporated in apple puree-alginate edible coating, on the shelf-life of fresh-cut
"Fuji" apples. During 21 days of storage at $4^{\circ} \mathrm{C}$, the coating with vanillin $(0.3 \% \mathrm{w} / \mathrm{w})$ was the most effective in terms of sensory quality. All the other studied antimicrobial coatings significantly inhibited growth of psychrophilic aerobes, yeasts, and moulds. The antimicrobial effect of essential oils against $L$. innocua inoculated into apple pieces before coating was also tested. A release system of antimicrobial volatiles was adopted by encapsulation of garlic oil in $\beta$-cyclodextrin and tested on microbial growth and sensory quality of fresh-cut tomato (Ayala-Zavala and GonzálezAguilar, 2010). Grape-fruit seed extract was used as antimicrobial compound into a coating of sodium alginate to prolong the shelflife of minimally processed kiwifruits. The combination of an active compound to an alginate-based coating delayed microbial growth, whereas the sole dipping treatment was inefficient. The combined use of modified atmosphere packaging (MAP) and coating treatments further prolonged the shelf-life up to 13 days (Mastromatteo et al., 2011a).

As reported by Krasaekoopt and Mabumrung (2008), the effectiveness of chitosan incorporated in the edible methyl cellulose coating on the microbiological quality of fresh-cut cantaloupe was evaluated. During storage at $10^{\circ} \mathrm{C}$ for 15 days, applications of 1.5 and $2 \%$ chitosan in the coating reduced growth of some pathogens, mesophilic aerobic bacteria (3.3 log cfu g $\mathrm{g}^{-1}$ ), 
psychrotrophs (3.9 $\log \mathrm{cfu}^{-1}$ ), lactic acid bacteria (3.1 log cfu $\left.\mathrm{g}^{-1}\right)$, yeasts and molds $\left(1.1 \log \mathrm{cfu} \mathrm{g}^{-1}\right)$, and total coliforms (3.8 $\log \mathrm{cfu}^{-1}$ ). An edible coating containing chitosan was also applied on carrot sticks to maintain quality and prolong the shelf-life (Simões et al., 2009). The coating application preserved the overall visual quality, the microbial proliferation and reduced surface whiteness during storage. While the content of total phenolics markedly increased in coated carrot sticks stored under moderate gas levels, it was controlled under low $\mathrm{O}_{2}$ and high $\mathrm{CO}_{2}$ levels. Film based on methyl cellulose incorporating chitosan and chitosan/methyl cellulose film incorporating vanillin were applied to fresh-cut cantaloupe and pineapple to control microbial quality during storage at $10^{\circ} \mathrm{C}$ (Sangsuwan et al., 2008). Chitosan/methyl cellulose film and vanillin films provided an inhibitory effect against E. coli in fresh-cut cantaloupe. The chitosan/methyl cellulose film rapidly reduced the number of S. cerevisiae inoculated on the products. For fresh-cut pineapples coating with vanillin was more efficient than chitosan/methyl cellulose in reducing the number of yeasts by 4 logs in six days. An edible coating with soy or wheat gluten protein as a carrier of thymol and calcium chloride was applied on strawberry by Atress et al. (2010). Treating fruits did not exhibit any change in fruit appearance until 9 days of storage. All treatments maintained ascorbic acid content, firmness, total sugar and reduced the total colony, moulds and yeasts compared to the control. The effect of sodium hypochlorite, peroxiacetic acid, acidified sodium chlorite and carvacrol on microbiological, sensory, and nutritional quality of fresh-cut jalapeno peppers stored at $5^{\circ} \mathrm{C}$ during 27 days was evaluated (Ruiz-Cruz et al., 2010). All sanitizers (except carvacrol) maintained microbiological and overall quality of jalapeno peppers during 27 days. Carvacrol, active ingredient of oregano essential oil, maintained shelf life for only 17 days and reduced sensory acceptability of fresh-cut produce. However, carvacrol-treated samples retained the highest levels of photochemical and antioxidant capacity.

Juices are food very susceptible to yeasts attack. Pichia anomala, S. cerevisiae, and Schizosaccharomyces pombe caused the most diffuse problems. Generally, heat treatment (pasteurization), aseptic packaging or use of weak acids exclude yeast spoilage. As alternative to these traditional artificial preservatives the use of natural compounds was proposed in the literature (Valero and Salmerón, 2003; Belletti et al., 2010). Clary, sage, juniper, lemon, and majoram essential oil were chosen to preserve apple juice, as being efficient in in vitro test and not containing phenolics but alcohol terpenoids, linalool (clary sage), and terpinen-4-ol (marjoram), the cyclic monoterpenes $\alpha$-pinene (juniper) and limonene (lemon) (Tserennadmid et al., 2011). The anti-yeast effects of these essential oils were good in the acidic $\mathrm{pH}$ range optimal for yeasts growth. Synergism or additive effects were recorded by combining the different active compounds. The most interesting result of the study of Tserennadmid et al. (2011) was recorded with lemon essential oil. In fact, experiments with lemon given to apple juices showed that the "open" storage time at ambient temperature could be prolonged and a novel, refreshing taste could be achieved.

Although the influence of smell-taste of some active agents is known, it has not often been evaluated to a sufficient degree.
One solution to the above-mentioned problem may be the use of combinations of different food preservation systems that would give the benefits of each of them while at the same time appreciably reducing the amount of antimicrobial required. For this reason, the application of moderate heat treatments and/or the preservation of the foodstuff in cold, refrigerated temperatures may play a key role. By using this method, a stable and, from a microbiological viewpoint, safe food can be produced without any loss in sensory quality. In this context various aroma compounds and citron essential oils containing citral, $\beta$-pinene, limonene, linalool, and $\alpha$-pinene, combined with mild heat treatment, were used to inhibit the growth of $S$. cerevisiae in non-carbonated soft drinks (Belletti et al., 2007).

\section{DAIRY PRODUCTS}

Fresh dairy products are ready-to-eat foods easily contaminated by undesirable microorganisms. Some of them are spoilage microorganisms which may produce unwanted visual appearance and diminish the commercial value of cheese, other ones are pathogens that affect product safety. Moreover, fungal spoilage can also occur. Recently, some studies have recorded the efficacy of natural compounds, alone or in combination with other preservation methods, when directly applied to milk (Cava et al., 2007) or to cheese by spraying, immersing, or dusting the products. Antimicrobials may also be spread onto the packaging materials that come in contact with the cheese or incorporated into the plastic films used for packaging (Conte et al., 2007). A brief overview of some recent examples of natural active agents applied to cheese is reported.

The effectiveness of lysozyme and EDTA on microbiological shelf life of mozzarella cheese was studied by Sinigaglia et al. (2008). Mozzarella was packaged in a brine that contained lysozyme $\left(0.25 \mathrm{mg} \mathrm{mL}^{-1}\right)$ and different amounts of EDTA $\left(10,20\right.$, and $\left.50 \mathrm{mmol} \mathrm{L}^{-1}\right)$, and stored at $4 \pm 1^{\circ} \mathrm{C}$ for 8 days. The packaging system significantly inhibited growth of coliforms and Pseudomonadaceae, without affecting the typical lactic acid bacteria. Conte et al. (2011) also evaluated the effects of lysozyme and EDTA in burrata cheese packaged under MAP $\left(95: 5 \mathrm{CO}_{2}: \mathrm{N}_{2}\right)$, thus demonstrating that these compounds were valid to prolong cheese shelf life, especially at high lysozyme concentrations.

Different release systems containing nisin and natamycin were also used in various works to create an additional hurdle for spoilage microorganisms in dairy products. For example, edible coatings made of galactomannans incorporating nisin were tested against $L$. monocytogenes in Ricotta cheese. The system not only help in retarding the growth of $L$. monocytogenes but also help in the maintenance of water content, therefore reducing cheese weight loss (Martins et al., 2010). Cao-Hoang et al. (2010) used sodium caseinate-based films for incorporating nisin to be active in mini red Babybel cheese. The active films affected L. innocua inoculated on cheese surface. As reported by Ture et al. (2011) natamycin was incorporated into wheat gluten and methyl cellulose biopolymers and tested against $A$. niger and $P$. roquefortii inoculated on surface of fresh kashar cheese. In a study conducted by Fajardo et al. (2010) natamycin was also used in combination with chitosan. In particular, the effects of the chitosan coating containing natamycin $(0.50 \mathrm{mg} / \mathrm{mL})$ on semi-hard 
cheese were assessed. The natamycin coated samples presented a decrease of moulds and yeasts compared to the control after 27 days of storage. The effects of nisin, natamycin, and their combination into a cellulose polymer matrix were also studied by dos Santos Pires et al. (2008). Films efficacy was first evaluated in vitro and then on sliced mozzarella cheese. Best effects were found when the two compounds were applied together on cheese.

As regards the applications of essential oils, numerous examples are reported in the literature (Table 2). The addition of different concentrations of lemon extract in the brine of mozzarella and in a gel solution made up of sodium alginate was evaluated by Conte et al. (2007). Shelf-life tests were run at $15^{\circ} \mathrm{C}$ to simulate thermal abuse. An increase in shelf-life of all active packaged mozzarella cheese was observed, confirming that the investigated substance may exert an inhibitory effect on the microorganisms responsible for spoilage, without affecting the typical dairy microbial population. As reported by Otaibi et al. (2008), three essential oils, thyme, marjoram and sage, were added to concentrated yoghurt (labneh) at concentrations of $0.2,0.5$, and $1.0 \mathrm{ppm}$. The better concentration of each essential oil was $0.2 \mathrm{ppm}$ that allowed obtaining a shelflife up to 21 days. Singh et al. (2011) also added essential oils in yogurt. The anise volatile oil and its oleoresin added to yogurt (prepared from buffalo's milk) (stored up to 20 days at $4 \pm 1^{\circ} \mathrm{C}$ ) at various concentrations $\left(0.1-1.0 \mathrm{~g} \mathrm{~L}^{-1}\right)$ were effective in controlling spoilage microorganisms. Eleven essential oils were evaluated in vitro for their antibacterial properties against Vancomycin-resistant Enterococci and E. coli O157:H7 (Selim, 2011). The most active essential oils against bacteria were thyme oil, eucalyptus, juniper, and clove oils. Furthermore, their effects were evaluated against the same microbial groups experimentally inoculated in Feta soft cheese and stored at $7^{\circ} \mathrm{C}$ for 14 days. The addition of thyme oil at concentrations of 0.5 and $1 \%$ caused a significant reduction in microbial growth. On Feta cheese inoculated with E. coli O157:H7 and L. monocytogenes oregano and thyme $(0.1$ or 0.2 and $0.1 \mathrm{ml} / 100 \mathrm{~g})$ combined with MAP were also tested by Govaris et al. (2011). In the control Feta microbial strains survived up to 1 month of storage. On the contrary, in Feta cheese treated with oils a significant reduction of microbial growth was found. The use of chitosan, lemon, and sage extract in Fior di latte cheese was assessed by Gammariello et al. (2010). Different concentrations of active substances were added during processing cow's milk. Lemon extract and chitosan showed a good compromise between the antimicrobial effectiveness and the sensory impact caused by their addition, thus promoting a satisfactory shelf life increase (129\%). In contrast, the addition of sage extract

Table 2 | Relevant examples of natural active compounds applied to dairy products.

\begin{tabular}{|c|c|c|c|}
\hline $\begin{array}{l}\text { Products and storage } \\
\text { conditions }\end{array}$ & Natural compounds & Main results & References \\
\hline
\end{tabular}

West African soft cheese

Treatment with eucalyptus oil and lemongrass oil

Ricotta cheese stored under modified atmosphere at $4^{\circ} \mathrm{C}$

Coating with a chitosan/whey protein edible film

Traditional Minas Serro cheese

Fresh cheese Tosèla

Caprese salad packaged under MAP $\left(65 \% \mathrm{~N}_{2}\right.$, $30 \% \mathrm{CO}_{2}$, and $5 \% \mathrm{O}_{2}$ )

Gorgonzola cheese

Antimicrobial compounds produced by six strains of non-starter lactic acid bacteria. In particular, Lactobacillus paracasei NdP78 was also found to produce a bacteriocin

Dipping with thymol (400 ppm)
Natamycin-incorporated film in the production process of cheese
The treatment of eucalyptus oil $75 \%$ plus $25 \%$

lemon grass exerted a positive impact on the nutritional, sensory, and microbial values of West African soft cheese

The chitosan/whey protein film slowed detrimental phenomena. The viable numbers of lactic acid bacteria and mesophilic and psychrotrophic microorganisms were significantly lower in the chitosan/whey protein coated cheese, compared to the control

Nisin was effective in reducing $S$. aureus count in Serro cheese. A reduction of 1.2 and $2.0 \mathrm{log}$ cycles in $S$. aureus count was observed from the 7 th day of ripening for cheese containing $100 \mathrm{IU} \mathrm{mL} \mathrm{mL}^{-1}$ and $500 \mathrm{IU} \mathrm{mL} \mathrm{m}^{-1}$ of nisin, respectively, compared with control sample

Cheese showed higher concentrations of lactobacilli (7.90 log CFU/g) and streptococci (6.10 log CFU/g), lower development of coliforms and staphylococci than control cheese

The combined use of thymol and MAP decreased the coliform populations from 5.65 to $4.23 \mathrm{log}$ CFU/g and extended the microbiological shelf-life from 3.77 to 12 days. It also decreased the concentration of Pseudomonadaceae

Films with 2 and $4 \%$ natamycin presented satisfactory results for $P$. roquefortii inhibition
Belewu et al., 2012

Di Pierro et al., 2011

Pinto et al., 2011

Settanni et al., 2011

Bevilacqua et al., 2007

de Oliveira et al., 2007 
negatively affected the sensory properties, thus making the cheese unacceptable.

Pires et al. (2009) developed a microbial sachet incorporated with allyl-isothiocyanate. Its efficiency was tested against yeasts, molds, Staphylococcus sp. and psychrotrophic bacteria in sliced mozzarella cheese stored at $12^{\circ} \mathrm{C} \pm 2{ }^{\circ} \mathrm{C}$. A reduction of $3.6 \mathrm{log}$ cycles was observed in yeasts and molds counts in the mozzarella packed with the antimicrobial sachet over 15 days of storage time. The sachet also showed an antibacterial effect on Staphylococcus sp.; however, psychrotrophic bacteria were very resistant. A new dairy product "Karishcum" obtained by adding Curcuma Longa (Curcumin or Turmeric) to classic Karish cheese at a rate of $0.3 \%$ (w/v) was realized in a study conducted by Hosny et al. (2011). A primary experiment was done to determine the correct percentage of Curcumin addition to cheese milk to get a good taste and a long shelf life. The behavior of pathogenic bacteria in the artificially contaminated product during cold storage for 14 days, revealed that addition of the extract $(0.3 \%)$ determined a reduction of bacterial counts of about $1 \log$ of $S$. Typhimurium and two $\log$ of P. aeurogenosa and E. coli 0157:H7.

\section{MEAT-BASED PRODUCTS}

Spoilage of meat products contributes to deterioration of texture and change in flavor and color. The use of natural antibacterial compounds, such as extracts of spices and herbs, essential oils, organic acids, salts, and bacteriocins is reported in the literature to improve the shelf life of meat (Jamilah et al., 2008; Jałosńska and Wilczak, 2009). Some applications are reported in Table 3.

Mastromatteo et al. (2011b) suggested the combined use of natural antimicrobials, such as lemon and thymol, and MAP to improve the shelf life of reduced pork back-fat content sausages. In particular, the application of thymol and thymol-MAP limited the development of Pseudomonas spp., responsible for sausages' unacceptability. The use of bay essential oil combined to MAP without oxygen $\left(20 \% \mathrm{CO}_{2}-80 \% \mathrm{~N}_{2}\right)$ was suggested to control $L$. monocytogenes and $E$. coli growth and also to extend the shelf life of naturally contaminated ground chicken meat (Irkin and Esmer, 2010). Moreover, the addition of essential oils of marjoram and rosemary to beef patties formulated with mechanically deboned poultry meat at a concentration of $200 \mathrm{mg} / \mathrm{kg}$ reduced lipid oxidation and improved the sensory characteristics

Table 3 | Relevant examples of natural active agents applied to meat-based products.

\begin{tabular}{|c|c|c|c|}
\hline $\begin{array}{l}\text { Products and storage } \\
\text { conditions }\end{array}$ & Natural compounds & Main results & References \\
\hline $\begin{array}{l}\text { Fresh minced beef } \\
\text { patties packaged under } \\
\text { MAP }\end{array}$ & Thymol $(250,500,750$ mg/Kg) & $\begin{array}{l}\text { Better effects on product quality were } \\
\text { obtained for sample with increased amount of } \\
\text { thymol, under MAP conditions (shelf life } \\
\text { about } 7 \text { days) }\end{array}$ & Del Nobile et al., 2009a \\
\hline $\begin{array}{l}\text { Minced beef mixed } \\
\text { with soy-protein stored } \\
\text { at } 4^{\circ} \mathrm{C}\end{array}$ & Sage essential oil $(0.1,0.3$, and $0.5 \%)$ & $\begin{array}{l}\text { The highest concentration of essential oil } \\
\text { controlled development of main } \\
\text { microorganisms }\end{array}$ & Ahmed and Ismail, 2010 \\
\hline $\begin{array}{l}\text { Meat-balls stored at } \\
10^{\circ} \mathrm{C}\end{array}$ & $\begin{array}{l}0.2 \% \text { of cranberry, rosemary, and lovage } \\
\text { extracts }\end{array}$ & $\begin{array}{l}\text { Rosemary extract was the most effective on } \\
\text { product shelf life ( } 13.3 \text { days) }\end{array}$ & Jałosńska and Wilczak, 20 \\
\hline $\begin{array}{l}\text { Sausages stored at } \\
4^{\circ} \mathrm{C} \text { under vacuum } \\
\text { conditions }\end{array}$ & $\begin{array}{l}\text { Sodium lactate }(0 \%, 0.6 \%, 1.2 \%, 1.8 \%) \text { as } \\
\text { alternative to nitrite }\end{array}$ & $\begin{array}{l}\text { Sodium lactate improved the microbiological } \\
\text { quality, extended shelf life, and exhibited a } \\
\text { better antimicrobial effect than nitrite }\end{array}$ & Bingöl and Bostan, 2007 \\
\hline Fresh sausage & Oregano and marjoram essential oil & $\begin{array}{l}\text { Addition of oregano and marjoram essential } \\
\text { oil exerted a bacteriostatic effect }\end{array}$ & Busatta et al., 2007, 2008 \\
\hline $\begin{array}{l}\text { Broiler chicken wings } \\
\text { stored at } 4^{\circ} \mathrm{C}\end{array}$ & $\begin{array}{l}\text { Dipping treatment for } 10 \text { min with chlorine } \\
\text { dioxide, lactic acid, and fumaric acid }\end{array}$ & $\begin{array}{l}\text { Samples treated with lactic acid alone } \\
\text { showed the most effective reduction on } \\
\text { E. coli and mesophylic bacteria }\end{array}$ & Hecer and Guldas, 2011 \\
\hline $\begin{array}{l}\text { Fresh chicken meat } \\
\text { stored under MAP at } \\
4^{\circ} \mathrm{C}\end{array}$ & $\begin{array}{l}\text { Treatments with nisin and EDTA, alone or } \\
\text { in combination }\end{array}$ & $\begin{array}{l}\text { Chicken was better preserved under } \\
\text { treatments with } 500 \mathrm{IU} / \mathrm{g} \text { of nisin and } 50 \mathrm{mM} \\
\text { of EDTA, even up to } 24 \text { days }\end{array}$ & Economou et al., 2009 \\
\hline Fresh beef & $\begin{array}{l}\text { Organic acids (citric, lactic, acetic, and } \\
\text { tartaric) }\end{array}$ & $\begin{array}{l}\text { Organic acids promoted a significant shelf life } \\
\text { extension }\end{array}$ & Jamilah et al., 2008 \\
\hline $\begin{array}{l}\text { Fresh chicken sausage } \\
\text { stored at } 4^{\circ} \mathrm{C}\end{array}$ & $\begin{array}{l}\text { Rosemary or Chinese mahogany (500, } \\
1000,1500 \text { ppm) }\end{array}$ & $\begin{array}{l}\text { Chinese mahogany and rosemary improved } \\
\text { meat quality }\end{array}$ & Liu et al., 2009 \\
\hline $\begin{array}{l}\text { Turkey-bologna stored } \\
\text { at } 4^{\circ} \mathrm{C}\end{array}$ & $\begin{array}{l}\text { Coating with gelatin containing Nisaplin } \\
\text { and Guardian }\end{array}$ & $\begin{array}{l}\text { Both Nisaplin film and Guardian film } \\
\text { effectively inhibited L. monocytogenes }\end{array}$ & Min et al., 2010 \\
\hline Meat pieces & Combined application of oregano essential & Combination of essential oils and organic & de Souza et al., 2009 \\
\hline
\end{tabular}

oil and acetic acid

acids inhibited microbial growth and

proliferation of pathogens such as $S$. aureus 
(Mohamed and Mansour, 2012). To reduce microbial growth and to preserve the oxidative stability of mortadella, a Bolognatype sausage, the addition of orange dietary fiber (1\%), rosemary essential oil $(0.02 \%)$ and thyme essential oil (0.02\%), combined with specific storage conditions, showed very desirable effects (Viuda-Martos et al., 2010, 2011). Antioxidant and antibacterial effects of rosemary, orange, and lemon extracts was also investigated in cooked Swedish-style meat-balls. Results indicated that significant advantages were obtained using rosemary and citrus extracts in rancidity-susceptible meat products; however, only rosemary slightly reduced lactic acid bacteria (Fernàndez-Lòpez et al., 2005). Ayachi et al. (2007) reported that the addition of a mixture of organic acids (sodium lactate $90 \%$ and sodium acetate $10 \%$ ) at different concentrations (from 0 to $20 \mathrm{~g} / \mathrm{Kg}$ ) on Marguez sausages, made with lamb and beef, significantly reduced microbial cell loads during storage at $8^{\circ} \mathrm{C}$.

Chitosan $(0.5 \%$ and $1 \%)$ added individually or in combination with nitrites $(150 \mathrm{ppm})$ as ingredients was tested to protect fresh pork sausages from microbial spoilage. Its application as active coating was demonstrated (Bostan and Isin-Mahan, 2011). Soultos et al. (2008) found chitosan active against total viable count, lactic acid bacteria, Pseudomonas spp., B. thermosphacta, Enterobacteriaceae, yeasts, and moulds.

Krisch et al. (2010) compared the antimicrobial effect of commercial herbs, spices and essential oils (fresh and dried garlic, onion, thyme, marjoram, and oregano) in minced pork. While fresh spices showed weak or no inhibition on viable cells of minced pork, some effects of essential oils were observed. Best shelf life values were obtained for pork meat added with garlic and marjoram oil. Dipping of thyme and oregano oil in concentrations of 0.1 and $0.3 \%$ were carried out to improve the shelf life of meat-based products (Karabagias et al., 2011). The combination of dipping and MAP extended the shelf life to about 22 days, against 7 days of the control sample packaged in air.

A relevant preservation effect for fresh chicken breast meat, stored at $4^{\circ} \mathrm{C}$, was obtained by dipping meat in oregano oil, prior to packaging under MAP (Chouliara et al., 2007). Fratianni et al. (2010) also proposed use of thyme and balm essential oils to decrease the natural microflora of chicken breast meat. In particular, balm essential oil significantly limited growth of Salmonella sp., whereas thyme essential oil effectively inhibited growth of E. coli. It was also widely demonstrated that dipping with lactic acid, clove oil and vitamin $\mathrm{C}$ can exert significant advantages over dipping with lactic acid alone to improve shelf life of buffalo meat steaks. In particular, use of clove oil along with lactic acid provided synergistic antioxidant and antimicrobial effects; the inclusion of vitamin $\mathrm{C}$ also stabilized product color (Naveena et al., 2006). Ntzimani et al. (2010) highlighted that combined use of EDTA, lysozyme, rosemary, and oregano oil extended shelf life of semi-cooked coated chicken fillets stored under vacuum packaging at $4^{\circ} \mathrm{C}$ to more than 2 weeks.

Effects of pork chops dipped in organic acids, such as ascorbic acid $(500 \mathrm{ppm})$ and citric acid $(250 \mathrm{ppm})$ individually or in combination, packaged under MAP and vacuum and stored at $1^{\circ} \mathrm{C}$ were studied by Huang et al. (2005). Ascorbic acid dipping reduced psychrotrophic microbial count, while ascorbic and citric acids improved lipid stability. The obtained results were enhanced by packaging under MAP conditions.

As regards bacteriocins, the combined use of lactoferrin and nisin on naturally contaminated Turkish-style meat-balls was proposed. Treatment with lactoferrin alone and in combination with nisin significantly reduced spoilage bacterial counts (total aerobic bacteria, coliform, E. coli, total psychrophilic bacteria, Pseudomonas spp., yeast and molds) and extended shelf life to 10 days (Colak et al., 2008). The synergistic antimicrobial activity of lysozyme, nisin, and EDTA against L. monocytogenes and meat-borne spoilage bacteria in ostrich patties packaged in air and vacuum was observed by Mastromatteo et al. (2010a). In particular, the antimicrobial treatment was effective for controlling growth of lactic acid bacteria even if it was not effective against Gram-negative bacteria.

\section{FISH-BASED PRODUCTS}

Fresh fish is a highly perishable product due to its biological composition. The main cause of deterioration is the activity of spoilage seafood microorganisms that provoke loss of essential fatty acids, fat-soluble vitamins and protein functionality, production of biogenic amines, and formation of off-odors (Gram and Dalgaard, 2002).

Literature widely demonstrates that treatments with natural compounds are effective preservation methods for fish products (Table 4). Different effects are generally exerted depending on the active agent used and on the characteristics of the raw material. Some examples are provided hereinafter. Erkan et al. (2011) proposed the use of thyme (1\%) and laurel essential oil (1\%) to extend the shelf life of bluefish by about 3-4 days. The quality of hot smoked rainbow trout packaged under vacuum and treated with thymol and garlic oil (1\%) was also improved (Erkan, 2012). Kykkidou et al. (2009) demonstrated that combination of MAP and thyme essential oil (0.1\%) resulted in a significant shelf life extension of fresh Mediterranean swordfish fillets. In particular, the addition of thyme essential oil extended product shelf life (13 days) if compared to the control (8 days), whereas its combination to MAP conditions further prolonged product shelf life (about 20.5 days). Goulas and Kontominas (2007) also showed that oregano essential oil (0.8\%) extended shelf life of sea bream fillet by more than 17 days. Similar results were also reported by Pyrgotou et al. (2010) on rainbow trout where the similar combined strategies reduced the cell load of main spoilage microorganisms. Corbo et al. (2008) highlighted the possibility to extend the microbial acceptability limit of fresh fish burgers by using a mix of thymol, grapefruit seed extract, and lemon extract. The mixture of the three natural compounds prolonged the sensory quality without compromising the flavor of fish. Each antimicrobial compound was first tested in vitro against the main fish spoilage microorganisms (Corbo et al., 2009). In a subsequent work, thymol, grapefruit seed extract, and lemon extract were used in combination to MAP to demonstrate that MAP further enhanced the effects of the natural active compounds. (Del Nobile et al., 2009b). Min et al. (2009) demonstrated the antimicrobial and antioxidant activity of purple rice bran extract against catfish patties. 
Table 4 | Relevant examples of natural active agents applied to fish-based products.

\begin{tabular}{|c|c|c|c|}
\hline $\begin{array}{l}\text { Products and storage } \\
\text { conditions }\end{array}$ & Natural compounds & Results & References \\
\hline $\begin{array}{l}\text { Rainbow trout fillets } \\
\text { packaged under } \\
\text { vacuum }\end{array}$ & Oregano essential oil $(0.2,0.4 \%)$ & $\begin{array}{l}\text { The combination of oregano }(0.2 \%) \text { and } \\
\text { vacuum resulted in a significant shelf life } \\
\text { extension of trout fillets ( } 11-12 \text { days) if } \\
\text { compared to the control packaged in air } \\
\text { ( } 5 \text { days) }\end{array}$ & Frangos et al., 2010 \\
\hline $\begin{array}{l}\text { Rainbow trout fillets } \\
\text { packaged with oxygen } \\
\text { absorber }\end{array}$ & Oregano essential oil (0.4\%) & $\begin{array}{l}\text { The antimicrobial compound improved the } \\
\text { sensory shelf life }\end{array}$ & Mexis et al., 2009 \\
\hline $\begin{array}{l}\text { Fish burgers packaged } \\
\text { under vacuum }\end{array}$ & Rosemary extract $0.4 \%$ and $0.8 \%$ & $\begin{array}{l}\text { Rosemary extract, in combination with } \\
\text { vacuum packaging was effective in } \\
\text { controlling microbial growth and } \\
\text { biochemical changes }\end{array}$ & Uçak et al., 2011 \\
\hline Fried mullet fish fillets & $\begin{array}{l}\text { Edible coating solution mixed with } \\
\text { thyme }(2.5,5 \%) \text { and marjoram } \\
(2.5,5 \%)\end{array}$ & $\begin{array}{l}\text { Thyme and marjoram have strong effects } \\
\text { against Enterobacteriaceae }\end{array}$ & Yasin and Abou-Taleb, 2007 \\
\hline $\begin{array}{l}\text { Sea bass fillets } \\
\text { packaged under } \\
\text { different MAP }\end{array}$ & Thyme essential oil (0.2\%) & $\begin{array}{l}\text { Essential oil improve the quality of sea } \\
\text { bass fillets when used in combination with } \\
60 \% \mathrm{CO}_{2}-30 \% \mathrm{~N}_{2}-10 \% \mathrm{O}_{2} \text {, providing a } \\
\text { shelf life of } 17 \text { days as compared to } 6 \text { days } \\
\text { of the control samples }\end{array}$ & Kostaki et al., 2009 \\
\hline $\begin{array}{l}\text { Cooked blue } \\
\text { swimming crab meat }\end{array}$ & $\begin{array}{l}\text { Sodium acetate dipping treatments } \\
(1,1.5 \text {, and } 2 \%)\end{array}$ & $\begin{array}{l}\text { Shelf life of product dipped in } 2 \% \text { for } 2 \text { min } \\
\text { was } 12 \text { days compared to the control } \\
\text { ( } 6 \text { days) }\end{array}$ & $\begin{array}{l}\text { Lohalaksanadech and Sujarit, } \\
2011\end{array}$ \\
\hline $\begin{array}{l}\text { Peeled shrimps } \\
\text { packaged under MAP }\end{array}$ & $\begin{array}{l}\text { Coating with thymol }(500,1000 \text {, } \\
1500 \text { ppm) }\end{array}$ & $\begin{array}{l}\text { Shelf life of about } 14 \text { days for the active } \\
\text { coating ( } 1000 \text { ppm) packaged under MAP } \\
\text { compared to the sample in air ( } 5 \text { days) was } \\
\text { obtained. }\end{array}$ & Mastromatteo et al., 2010b \\
\hline
\end{tabular}

Coatings enriched with essential oils were also proposed in literature as valid technique to improve quality of fish products. As example, Ojagh et al. (2010) reported that the use of a coating with chitosan and cinnamon essential oil improved trout fillet shelf life (16 days vs. 10 days of the control) and in particular it enhanced texture, odor, and color. Similar results were also obtained for trout fresh fillets coated with gelatin enriched with cinnamon oil $(1 \%, 1.5 \%$, and $2 \%)$. In particular, experimental data indicated that the active coating can be suitable for preserving the fillets and maintain quality to an acceptable level (Andevari and Rezaei, 2011).

To control quality of northern snakehead fish fillets at refrigeration temperature cinnamon, coatings with nisin and EDTA, alone and in combination were used (Lu et al., 2010).

Acetic acid, glucono-delta-lactone and chitosan were tested, individually and in combination, to inhibit microbial growth in surimi. The results showed that microbial proliferation was successfully inhibited by packaging the fish ball in 1\% chitosan dissolved in 1\% of acetic acid (Kok and Park, 2007). Shirazinejad et al. (2010) evaluated the use of lactic acid alone and in combination with nisin for reducing microorganisms on chilled shrimp. Best results against Pseudomonas spp. were obtained for samples treated with the mixture of lactic acid and nisin.

\section{CEREAL-BASED PRODUCTS}

Shelf life of bread is generally limited due to the staling phenomenon and fungi spoilage, in particular moulds. Among strategies aimed to improve quality of bread, some effects were reported by using different natural compounds. In particular, it was reported that chitosan coating improved bread quality by inhibiting microbial growth and retarding oxidation and staling. A reduced microbial proliferation was obtained for bread coated with chitosan during storage at room temperature (No et al., 2007).

Rehman et al. (2007) reported different applications of citrus peel essential oils in bread. Results demonstrated that the oils influenced sensory characteristics and delayed microbial growth. Maximum inhibitory effect against moulds and bacteria was achieved by spraying peel essential oil. The combination of MAP and mustard oil was proposed for wheat and rye bread artificially inoculated with moulds (Suhur and Nielsen, 2005).

Breads prepared from wheat flour by adding different additives were also evaluated by Latif et al. (2005). The studies on colony count in bread at different storage time showed that treatment containing $0.32 \%$ of suhanjna, $3 \%$ of lecithin, and $0.1 \%$ of ascorbic acid proved to be most effective. The different combination of the three selected natural additives improved bread 
shelf life. In particular, lower cell loads of yeasts and moulds were observed for bread with lecithin and ascorbic acid (Latif and Masud, 2006). An active packaging with cinnamon essential oil combined with MAP was tested to increase the shelf life of gluten-free sliced bread. Results showed that the active packaging is better than MAP to increase product shelf life because it inhibited microbial growth while maintaining the sensory properties of the gluten-free bread (Gutiérrez et al., 2011).

Natural active compounds were also applied to fresh pasta that is a product easily perishable for its high water content. Del Nobile et al. (2009c) proposed the use of different natural antimicrobial compounds such as thymol, lemon extract, chitosan, and grapefruit seed extract at different concentrations $(2000 \mathrm{mg} / \mathrm{kg}$ and $4000 \mathrm{mg} / \mathrm{kg}$ ) to improve the microbiological stability of refrigerated amaranth-based fresh pasta. Results pointed out that chitosan were the most successful among the investigated compounds in slowing down the spoilage, whereas lemon extract was the less effective. In a subsequent work, the antimicrobial activity of chitosan in combination with different MAP was tested. It was found that among the tested MAP conditions, the combination of 30:70 $\mathrm{N}_{2}: \mathrm{CO}_{2}$ extended the shelf life beyond two months (Del Nobile et al., 2009d). The antimicrobial activity of chitosan against the main microorganisms of fresh pasta was also reported by Costa et al. (2010). In particular, statistically significant differences were found between the shelf life of pasta with chitosan packaged under MAP conditions in a low barrier film made up of polypropylene and in a multilayer high barrier film made up of polyethylene terephthalate, ethylene-vinyl alcohol, and polyethylene.

To improve the shelf life of yellow alkaline noodle Rosyid et al. (2011) tested the antibacterial activity of ethanol and water extracts of six types of leaves against the principal spoilage microbial groups of this product. Results highlighted that ethanol extracts of aromatic leaf, Murraya koenigii L., added in yellow alkaline noodle contributed to improve shelf life better than the other extracts. Budka and Khan (2010) demonstrated that essential oils from basil, thyme and oregano exhibit bactericidal properties against $B$. cereus in rice-based foods. The antioxidant and antimicrobial activity of different natural compounds (anise, black cumin, rosemary and sage) were also tested to increase shelf life of some bakery products. Preliminary results showed that both Gram-positive and Gram-negative bacteria were sensitive to all tested essential oils and phenolic compounds (Basuny et al., 2012).

\section{CONCLUDING REMARKS AND FUTURE PERSPECTIVES}

Most food products require protection against microbial spoilage during storage. Consumers demand safe natural products. This drives the search of food authorities and researchers for mild preservation techniques to improve microbial quality and safety without causing nutritional and organoleptic losses. In this context natural compounds are gaining a great interest from research and industry, due to the potential to provide quality and safety benefits, with a reduced impact on human health. In addition, utilization of natural active agents promotes the accepted criteria of food sustainability. The numerous experimental applications of essential oils, enzymes, bacteriocins, chitosans, and organic acids to various fresh perishable foods demonstrate that they are well suited to be utilized as preservatives in foods and could be often valid alternatives to synthetic food additives. However, there is a need to search for new sources of antimicrobial substances, including plant metabolites. Natural products have been the most successful source of drugs ever. Historically, the most important natural sources have been plants. Research progressed along two major lines: ethnopharmacology (medicinal herbs, substances of abuse, ordeal poisons) and toxicology (poisonous plants, venomous animals, arrow, and fish poisons). These strategies have produced many valuable drugs and are likely to continue to produce lead compounds. It must be stated that traditional medicines have not been found by systematic research but by a combination of coincidence and observation, and at best by trial and error. In order to further promote the application of natural active compounds at industrial level, some factors are of striking importance. First of all it is necessary to have a good understanding of the mechanism by which antibacterial agents operate. For many natural compounds these information are still lacking. Better understanding of the modes by which antimicrobials can control microorganisms should provide solid grounds for engineering new and upgraded derivatives with optimized potency and stability. Further research is still necessary for specific casestudy because it is well demonstrated that the combination of more than one active agent not always amplifies the antimicrobial effects. Very often, the combined use of some natural essential oils did not induce synergistic effects. So, generally specking some considerations must be taken into account before using antimicrobials in food preservation. One of them is the possible existence of interactions between compounds and food components. Moreover, also the adoption of active compounds under MAP conditions could exert different effects depending on the product.

In the specific case of essential oils, despite their great potential, their use in food preservation remains limited mainly due to their intense aroma and toxicity problems. Several authors have reported changes in the organoleptic properties of the food when these oils are used. To minimize the required doses and improve the effectiveness of active coatings enriched with essential oils, interesting options would be micro- and nanoencapsulation of active compounds. In addition, the use of combinations of different food preservation systems, such as the use of proper temperature, could represent another solution to the above-mentioned problem. As regards toxicity, the ingestion of high doses of essential oils can induce serious problems. Thus, it is necessary to find a balance between the effective compound dose and the risk of toxicity. It is also worth noting that the use of essential oils remains expensive, so from an economic point of view this preservation strategy needs further enhancement. Moreover, more specific ISO standards are also necessary to assess the legal aspects to set out the definition, the general rules for their use, the requirements for labeling and the maximum levels authorized. 


\section{REFERENCES}

Ahmed, A. M., and Ismail, T. H. (2010). Improvement of the quality and shelf-life of minced-beef mixed with soyprotein by Sage (Salvia officinalis). Afr. J. Food Sci. 4, 330-334.

Andevari, G. T., and Rezaei, M. (2011). Effect of gelatin coating incorporated with cinnamon oil on the quality of fresh rainbow trout in cold storage. Int. J. Food Sci. Technol. 46, 2305-2311.

Ansorena, M. R., Marcovichb, N. E., and Roura, S. I. (2011). Impact of edible coatings and mild heat shocks on quality of minimally processed broccoli (Brassica oleracea L.) during refrigerated storage. Postarv. Biolog. Technol. 59, 53-63.

Appendini, P., and Hotchkiss, J. H. (2002). Review of antimicrobial food packaging. Inno. Food Sci. Emerg. Technol. 3, 113-126.

Atress, A. S. H., El-Mogy, M. M., Aboul-Anean, H. E., and Alsanius B. W. (2010). Improving strawberry fruit storability by edible coating as a carrier of thymol or calcium chloride. J. Horticult. Sci. Ornam. Plants 2, 88-97.

Ayachi, B. E., Daoudi, A., and Benkerroum, N. (2007). Effectiveness of commercial organic acids' mixture (Acetolac ${ }^{\mathrm{TM}}$ ) to extend the shelf life and enhance the microbiological quality of Merguez sausages. Am. J. Food Technol. 2, 190-195.

Ayala-Zavala, J. F., and GonzálezAguilar, G. A. (2010). Optimizing the use of garlic oil as antimicrobial agent on fresh-cut tomato through a controlled release system. J. Food Sci. 75, 398-405.

Ayala-Zavala, J. F., Oms-Oliu, G., Odriozola-Serrano, I., GonzálezAguilar, G. A., Álvarez-Parrilla, E., and Martín-Belloso, O. (2008). Biopreservation of fresh-cut tomatoes using natural antimicrobials. Eur. Food Res. Technol. 226, 1047-1055.

Bae, Y. M., Choi, N. Y., Heu, S., Kang, D. H., and Lee, S. Y. (2011). Inhibitory effects of organic acids combined with modified atmosphere packaging on foodborne pathogens on cabbage. J. Korean Soc. Appl. Biol. Chem. 54, 993-997.

Basuny, A. M., Nasef, S. L., Mahmoud, E. A. M., and Arafat, S. M. (2012). Use of medicinal and aromatic plants for increasing quality of some bakery products. Int. Sci. Invest. J. 1, 1-22.

Belewu, M. A., Ahmed El-Imam, A. M., Adeyemi, K. D., and Oladunjoye, S. A. (2012). Eucalyptus oil and lemon grass oil: effect on chemical composition and shelf-life of soft cheese. Env. Nat. Resour. Res. 2, 114-118.

Belletti, N., Kamdem, S. S., Patrignani, F., Lanciotti, R., Covelli, A., and Gardini, F. (2007). Antimicrobial activity of aroma compounds against Saccharomyces cerevisiae and improvment of microbiological stability of soft drinks as assessed by logistic regression. Appl. Environ. Microbiol. 73, 5580-5586.

Belletti, N., Kamdem, S. S., Tabanelli, G., Lanciotti, R., and Gardini, F. (2010). Modeling of combined effects of citral, linalool and Bpinene used against Saccharomyces cerevisiae in citrus-based beverages subjected to a mild heat treatment. Int. J. Food Microbiol. 136, 283-289.

Belletti, N., Lanciotti, R., Patrignani, F., and Gardini, F. (2008). Antimicrobial efficacy of citron essential oil on spoilage and pathogenic microorganisms in fruit-based salads. J. Food Sci. 73, 331-338.

Bevilacqua, A., Corbo, M. R., and Sinigaglia, M. (2007). Combined effects of modified atmosphere packaging and thymol for prolonging the shelf life of caprese salad. J. Food Prot. 70, 722-728.

Bico, S. L. S., Raposo, M. F. J., Morais, R. M. S. C., and Morais, A. M. M. B. (2009). Combined effects of chemical dip and/or carrageenan coating and/or controlled atmosphere on quality of fresh-cut banana. Food Contr. 20, 508-514.

Bingöl, E. B., and Bostan, K. (2007). Effect of sodium lactate on the microbiological quality and shelf life of sausages. Turk. J. Vet. Anim. Sci. 31, 333-339.

Bostan, K., and Isin-Mahan, F. (2011). Microbiological quality and shelflife of sausage treated with chitosan. J. Fac. Vet. Med. Istanbul Univ. 37, 117-126.

Branen, J. K., and Davidson, P. M. (2004). Enhancement of nisin, lysozyme, and monolaurin antimicrobial activities by ethylene diamine tetraacetic acid and lactoferrin. Int. J. Food Microbiol. 90, 63-67.

Brasil, I. M., Gomes, C., PuertaGomez, A., Castell-Perez, M. E., and Moreira, R. G. (2012). Polysaccharide-based multilayered antimicrobial edible coating enhances quality of fresh-cut papaya. Food Sci. Technol. 47, 39-45.

Brewer, R., Adams, M. R., and Park, S. F. (2002). Enhanced inactivation of Listeria monocytogenes by nisin in the presence of ethanol. Lett. Appl. Microbiol. 34, 18-21.
Budka, D., and Khan, N. A. (2010). The effect of Ocimum basilicum, Thymus vulgaris, Origanum vulgare essential oils on Bacillus cereus in rice-based foods. EJBS 2, 17-20.

Busatta, C., Mossi, A. J., Alves Rodrigues, M. R., Cansian, R. L., and de Oliveira, J. V. (2007) Evaluation of Origanum vulgare essential oil as antimicrobial agent in sausage. Braz. J. Microbiol. 38, 610-616.

Busatta, C., Vidal, R. S., Popiolski, A. S., Mossi, A. J., Dariva, C., Rodrigues, M. R. A., Corazza, F. C., Corazza, M. L., Oliveira, V. J., and Cansian, R. L. (2008). Application of Origanum majorana L. essential oil as an antimicrobial agent in sausage. Food Microbiol. 25, 207-211.

Campaniello, D., Bevilacqua, A., Sinigaglia, M., and Corbo, M. R. (2008). Chitosan: antimicrobial activity and potential applications for preserving minimally processed strawberries. Food Microbiol. 25, 992-1000.

Cao-Hoang, L., Grégoire, L., Chaine, A., and Waché, Y. (2010). Importance and efficiency of in-depth antimicrobial activity for the control of listeria development with nisin-incorporated sodium caseinate films. Food Contr. 21, 1227-1233.

Cava, R., Nowak, E., Taboada, A., and Marin-Iniesta, F. (2007). Antimicrobial activity of clove and cinnamon essential oils against Listeria monocytogenes in pasteurized milk. J. Food Prot. 70, 2757-2763.

Chouliara, E., Karatapanis, A., Savvaidis, I. N., and Kontominas, M. G. (2007). Combined effect of oregano essential oil and modified atmosphere packaging on shelf-life extension of fresh chicken breast meat, stored at $4^{\circ} \mathrm{C}$. Food Microbiol. 24, 607-617.

Colak, H., Hampikyan, H., Bingol, E. B., and Aksu, H. (2008). The effect of risine and bovine lactoferrin on the microbiological quality of turkish-style meatball (Tekirdag Köfte). J. Food Saf. 28, 355-375.

Conte, A., Brescia, I., and Del Nobile, M. A. (2011). Lysozyme/EDTA disodium salt and modifiedatmosphere packaging to prolong the shelf life of burrata cheese. J. Dairy Sci. 94, 5289-5297.

Conte, A., Scrocco, C., Sinigaglia, M., and Del Nobile, M. A. (2007). Innovative active packaging systems to prolong the shelf life of Mozzarella cheese. J. Dairy Sci. 90, 2126-2131.
Corbo, M. R., Di Giulio, S., Conte, A., Speranza, B., Sinigaglia, M., and Del Nobile, M. A. (2009). Thymol and modified atmosphere packaging to control microbiological spoilage in packed fresh cod hamburgers. Int. J. Food Sci. Technol. 44, 1553-1560.

Corbo, M. R., Speranza, B., Filippone, A., Granatiero, S., Conte, A., Sinigaglia, M., and Del Nobile, M. A. (2008). Study on the synergic effect of natural compounds on the microbial quality decay of packed fish hamburger. Int. J. Food Microbiol. 127, 261-267.

Costa, C., Lucera, A., Mastromatteo, M., Conte, A., and Del Nobile, M. A. (2010). Shelf life extension of durum semolina-based fresh pasta. Int. J. Food Sci. Technol. 45, 1545-1551.

Cunningham, F. E., Proctor, V. A., and Goetsch, S. J. (1991). Egg white lysozyme as food preservative: an overview. Worlds Poult. Sci. J. 47, 141-163.

Davidson, P. M., and Taylor, M. T. (2007). "Chemical preservatives and natural antimicrobial compounds", in Food Microbiology: Fundamentals and Frontiers, eds P. Doyle, L. R. Beuchat, and T. J. Montville (Washington, DC: American Society for Microbiology Press), 713-734.

Delaquis, P. J., and Mazza, G. (1995). Antimicrobial properties of isothiocyanates and their role in food preservation. Food Technol. 49, 73-84.

Del Nobile, M. A., Conte, A., Cannarsi, M., and Sinigaglia, M. (2009a). Strategies for prolonging the shelf life of minced beef patties. J. Food Saf. 29, 14-25.

Del Nobile, M. A., Corbo, M. R., Speranza, B., Sinigaglia, M., Conte, A., and Caroprese, M. (2009b). Combined effect of MAP and active compounds on fresh blue fish burger. Int. J. Food Sci. Microbiol. 135, 281-287.

Del Nobile, M. A., Di Benedetto, N., Suriano, N., Conte, A., Lamacchia, C., Corbo, M. R., and Sinigaglia, M. (2009c). Use of natural compounds to improve the microbial stability of Amaranth-based homemade fresh pasta. Food Microbiol. 26, 151-156.

Del Nobile, M. A., Di Benedetto, N., Suriano, N., Conte, A., Corbo, M. R., and Sinigaglia, M. (2009d). Combined effects of chitosan and MAP to improve the microbial quality of Amaranth homemade fresh pasta. Food Microbiol. 26, 587-591.

de Oliveira, T. M., de Fátima Ferreira Soares, N., Pereira, R. M., and 
de Freitas Fraga, K. (2007). Development and evaluation of antimicrobial natamycinincorporated film in Gorgonzola cheese conservation. Packag. Technol. Sci. 20, 147-153.

de Souza, E. L., de Barros, J. C., da Conceição, M. L., Gomes Neto, N. J., and da Costa, A. C. V. (2009). Combined applications of Origanum vulgare L. essential oil and acetic acid for controlling the growth of Staphylococcus aureus in foods. Braz. J. Microbiol. 40, 387-393.

Di Pierro, P., Sorrentino, A., Mariniello, L., Giosafatto, C. V. L., and Porta, R. (2011). Chitosan/whey protein film as active coating to extend Ricotta cheese shelf-life. Food Sci. Technol. 44, 2324-2327.

Dorman, H. J. D., and Deans, S. G. (2000). Antimicrobial agents from plants: antibacterial activity of plant volatile oils. J. Appl. Microbiol. 88, 308-316.

dos Santos Pires, A. C., Ferreira Soares, N., de Andrade, N. J., Mendes da Silva, L. H., Peruch Camilloto, G., and Campos Bernardes, P. (2008). Development and evaluation of active packaging for sliced mozzarella preservation. Packag. Technol. Sci. 21, 375-383.

Economou, T., Pournis, N., Ntzimani, A., and Savvaidis, I. N. (2009). Nisin-EDTA treatments and modified atmosphere packaging to increase fresh chicken meat shelf-life. Food Chem. 114, 1470-1476.

Erkan, N. (2012). The effect of thyme and garlic oil on the preservation of vacuum-packaged hot smoked rainbow trout (Oncorhynchus mykiss). Food Bioprocess Technol. 5, 1246-1254.

Erkan, N., Tosun, S. Y., Ulusoy, S., and Üretener, G. (2011). The use of thyme and laurel essential oil treatments to extend the shelf life of bluefish (Pomatomus saltatrix) during storage in ice. J. Consum. Protec. Food Saf. 6, 39-48.

Fajardo, P., Martins, J. T., Fuciños, C., Pastrana, L., Teixeira, J. A., and Vicente, A. A. (2010). Evaluation of a chitosan-based edible film as carrier of natamycin to improve the storability of Saloio cheese. J. Food Eng. 101, 349-356.

Farkas, J. (2007). "Physical methods of food preservation", in Food Microbiology: Fundamentals and Frontiers, eds. P. Doyle, L. R. Beuchat, and T. J. Montville (Washington, DC: American Society for Microbiology Press), 685-705.
Fernàndez-Lòpez, J., Zhi, N., AlesonCarbonell, L., Pèrez-Alvarez, J. A., and Kuri, V. (2005). Antioxidant and antibacterial activities of natural extracts: application in beef meatballs. Meat Sci. 69, 371-380.

Frangos, L., Pyrgotou, N., Giatrakou, V., Ntzimani, A., and Savvaidis, I. N. (2010). Combined effects of salting, oregano oil and vacuum-packaging on the shelf-life of refrigerated trout fillets. Food Microbiol. 27, 115-121.

Fratianni, F., De Martino, L., Melone, A., De Feo, V., Coppola, R., and Nazzaro, F. (2010). Preservation of chicken breast meat treated with thyme and balm essential oils. J. Food Sci. 75, 528-535.

Gálvez, A., Abriouel, H., López, R. L., and Omar, N. B. (2007). Bacteriocin-based strategies for food biopreservation. Int. J. Food Microbiol. 120, 51-70.

Gammariello, D., Conte, A., and Del Nobile, M. A. (2010). Assessment of chitosan and extracts of lemon and sage as natural antimicrobial agents during Fior di latte cheesemaking. Int. J. Dairy Technol. 63, 530-537.

Goulas, A. E., and Kontominas, M. G. (2007). Combined effect of light salting, modified atmosphere packaging and oregano essential oil on the shelf-life of sea bream (Sparus aurata): biochemical and sensory attributes. Food Chem. 100, 287-296.

Govaris, A., Botsoglou, E., Sergelidis, D., and Chatzopoulou, P. S. (2011). Antibacterial activity of oregano and thyme essential oils against Listeria monocytogenes and Escherichia coli O157, H7 in feta cheese packaged under modified atmosphere. Food Sci. Technol. 44, 1240-1244.

Gram, L., and Dalgaard, P. (2002). Fish spoilage bacteria-problems and solutions. Curr. Opin. Biotechnol. 13, 262-266.

Gutierrez, J., Barry-Ryan, C., and Bourke, P. (2008). The antimicrobial efficacy of plant essential oil combinations and interactions with food ingredients. Int. J. Food Microbiol. 124, 91-97.

Gutierrez, J., Barry-Ryan, C., and Bourke, P. (2009). Antimicrobial activity of plant essential oils using food model media: efficacy, synergistic potential and interaction with food components. Food Microbiol. 26, 142-150.

Gutiérrez, L., Batlle, R., Andújar, S., Sánchez, C., and Nerín, C. (2011). Evaluation of antimicrobial active packaging to increase shelf life of gluten free sliced bread. Pack. Technol. Sci. 24, 485-494.

Hanušová, K., Dobiáš, J., and Klaudisová, K. (2009). Effect of packaging films releasing antimicrobial agents on stability of food products. Czech J. Food Sci. 27, 347-349.

Hecer, C., and Guldas, M. (2011). Effects of lactic acid, fumaric acid and chlorine dioxide on shelf-life of broiler wings during storage. Afr. J. Microbiol. Res. 23, 3880-3883.

Hesham, A. A. E. (2008). Effect of chitosan coating on shelf-life and quality of fresh-cut mushroom. Pol. J. Food Nutr. Sci. 58, 95-105.

Hosny, I. M., El Kholy, W. I., Murad, H. A., and El Dairouty, R. K. (2011). Antimicrobial activity of Curcumin upon pathogenic microorganisms during manufacture and storage of a novel style cheese "Karishcum". J. Am. Sci. 7 , 611-618.

Huang, N. Y., Ho, C. P., and McMillin, K. W. (2005). Retail shelf-life of pork dipped in organic acid before modified atmosphere or vacuum packaging. J. Food Sci. 70 , 382-387.

Irkin, R., and Esmer, O. K. (2010) Control of Listeria monocytogenes in ground chicken breast meat under aerobic, vacuum and modified atmosphere packaging conditions with or without the presence of bay essential oil at $4^{\circ} \mathrm{C}$. Food Sci. Technol. Res. 16, 285-290.

Jałosńska, M., and Wilczak, J. (2009). Influence of plant extracts on the microbiological shelf life of meat products. Pol. J. Food Nutr. Sci. 59, 303-308.

Jamilah, M. B., Abbas, K. A., and Rahman, R. A. (2008). A review on some organic acids additives as shelf life extenders of fresh beef cuts. Am. J. Agric. Biol. Sci. 3, 566-574.

Jiang, Y., and Li, Y. (2001). Effects of chitosan coating on postharvest life and quality of longan fruit. Food Chem. 73, 139-143.

Karabagias, I., Badeka, A., and Kontominas, M. G. (2011). Shelf life extension of lamb meat using thyme or oregano essential oils and modified atmosphere packaging. Meat Sci. 88, 109-116.

Kok, T. N., and Park, J. W. (2007). Extending the shelf life of set fish ball. J. Food Qual. 30, 1-27.

Kostaki, M., Giatrakou, V., Savvaidis, I. N., and Kontominas, M. G. (2009). Combined effect of MAP and thyme essential oil on the microbiological, chemical and sensory attributes of organically aquacultured sea bass (Dicentrarchus labrax) fillets. Food Microbiol. 26, 475-482.

Krasaekoopt, W., and Mabumrung, J. (2008). Microbiological Evaluation of Edible Coated Fresh-Cut Cantaloupe. Kasetsart J. (Nat. Sci.) 42, 552-557.

Krisch, J., Pardi, Z., Tserennadmid, R., Papp, T., and Vágvölgyi, C. (2010). Antimicrobial effects of commercial herbs, spices and essential oils in minced pork. Acta Biol. Szeged. 54 131-134.

Kykkidou, S., Giatrakou, V., Papavergou, A., Kontominas, M. G., and Savvaidis, I. N. (2009), Effect of thyme essential oil and packaging treatments on fresh Mediterranean swordfish fillets during storage at $4^{\circ} \mathrm{C}$. Food Chem. $115,169-175$

Latif, A., Masood, T., and Khan, H. A. (2005). Quality improvement and shelf life extension of bread. J. Agric. Soc. Sci. 1, 109-113.

Latif, A., and Masud, T. (2006). Use of natural preservative in bread making. Am. J. Food Technol. 1, 34-42.

Liu, D. C., Tsau, R. Z., Lin, Y. C., Jan, S. S., and Tan, F. J. (2009). Effect of various levels of rosemary or Chinese mahogany on the quality of fresh chicken sausage during refrigerated storage. Food Chem. $117,106-113$.

Lohalaksanadech, S., and Sujarit, C. (2011). "Shelf life extension of refrigerated storage of blue swimming crab meat (Portunus pelagicus) by dipping in sodium acetate," in 37th Congress on Science and Technology of Thailand, (Bangkok), October 10-12-2011, 1-6.

Lòpez-Malo, A., Maris Alzamora, S., and Palou, E. (2005). Aspergillus flavus growth in the presence of chemical preservatives and naturally occurring antimicrobial compounds. Int. J. Food Microbiol. 99, 119-128.

Lopez-Pedemonte, T. J., Roig-Sagues, A. X., Trujillo, A. J., Capellas, M., and Guamis, B. (2003). Inactivation of spores of Bacillus cereus in cheese by high hydrostatic pressure with the addition of nisin or lysozyme. J. Dairy Sci. 86, 3075-3081.

Lu, F., Ding, Y., Ye, X., and Liu, D. (2010). Cinnamon and nisin in alginate-calcium coating maintain quality of fresh northern snakehead fish fillets. Food Sci. Technol. 43, 1331-1335.

Mangena, T., and Muyima, N. Y. O. (1999). Comparative evaluation of the antimicrobial activities of essential oils of Artemisia afra, Pteronia incana and Rosemarinu 
officinalis on selected bacteria and yeast strains. Lett. Appl. Microbiol. 28, 291-296.

Marino, M., Bersani, C., and Comi, G. (2001). Impedance measurement to study antimicrobial activity of essential oils from Lamiaceae and Compositae. Int. J. Food Microbiol. 67, 187-195.

Martins, J. T., Cerqueira, M. A., Souza, B. W. S., Avides, M. D. C., and Vicente, A. A. (2010). Shelf life extension of ricotta cheese using coatings of galactomannans from nonconventional sources incorporating nisin against Listeria monocytogenes. Agric. Food Chem. 58, 1884-1891.

Mastromatteo, M., Lucera, A., Sinigaglia, M., and Corbo, M. R. (2010a). Synergic antimicrobial activity of lysozyme, nisin, and EDTA against Listeria Monocytogenes in Ostrich meat patties. J. Food Sci. 75, 422-429.

Mastromatteo, M., Danza, A., Conte, A., Muratore, G., and Del Nobile, M. A. (2010b). Shelf life of ready to use peeled shrimps as affected by thymol essential oil and modified atmosphere packaging. Int. J. Food Microbiol. 144, 250-256.

Mastromatteo, M., Mastromatteo, M., Conte, A., and Del Nobile, M. A. (2011a). Combined effect of active coating and MAP to prolong the shelf life of minimally processed kiwifruit (Actinidia deliciosa cv. Hayward). Food Res. Int. 44, 1224-1230.

Mastromatteo, M., Incoronato, A. L., Conte, A., and Del Nobile, M. A. (2011b). Shelf life of reduced pork back-fat content sausages as affected by antimicrobial compounds and modified atmosphere packaging. Int. J. Food Microbiol. 150, 1-7.

Mexis, S. F., Chouliara, E., and Kontominas, M. G. (2009). Combined effect of an oxygen absorber and oregano essential oil on shelf life extension of rainbow trout fillets stored at $4^{\circ} \mathrm{C}$. Food Microbiol. 26, 598-605.

Min, B., Chen, M. H., and Green, B. W. (2009). Antioxidant activities of purple rice bran extract and its effect on the quality of low- $\mathrm{NaCl}$, phosphate-free patties made from channel catfish (Ictalurus punctatus) belly flap meat. J. Food Sci. 74, 268-277.

Min, B. J., Han, I. Y., and Dawson, P. L. (2010). Antimicrobial gelatin films reduce Listeria monocytogenes on turkey bologna. Poultry Sci. 89, 1307-1314.

Mohamed, H. M. H., and Mansour, H. A. (2012). Incorporating essential oils of marjoram and rosemary in the formulation of beef patties manufactured with mechanically deboned poultry meat to improve the lipid stability and sensory attributes. Food Sci. Technol. 45, 79-87.

Muthukumarasamy, P., Han, J. H., and Holley, R. A. (2003). Bactericidal effects of Lactobacillus reuteri and allyl isothiocyanate on E. coli $\mathrm{O} 157$, $\mathrm{H} 7$ in refrigerated ground beef. J. Food Prot. 66, 2038-2044.

Nadarajah, D., Han, J. H., and Holley, R. A. (2002). "Use of allyl isothiocyanate to reduce E. coli O157:H7 in packaged ground beef patties," Institute of Food Technology Annual Meeting, Abstract \# 100B-15. (Anaheim, CA).

Naveena, B. M., Muthukumar, M., Sen, A. R., Babji, Y., and Murthy, T. R. K. (2006). Improvement of shelf-life of buffalo meat using lactic acid, clove oil and vitamin C during retail display. Meat Sci. 74, 409-415.

No, H. K., Meyers, S. P., Prinyawiwatkul, W., and $\mathrm{Xu}, \mathrm{Z}$. (2007). Application of chitosan for improvement of quality and shelf life of foods: a review. J. Food Sci. $72,100-187$.

Ntzimani, A. G., Giatrakou, V. I., and Savvaidis, I. N. (2010). Combined natural antimicrobial treatments (EDTA, lysozyme, rosemary and oregano oil) on semi cooked coated chicken meat stored in vacuum packages at $4^{\circ} \mathrm{C}$ : Microbiological and sensory evaluation. Innov. Food Sci. Emerg. Technol. 11, 187-196.

Ojagh, S. M., Rezaei, M., Razavi, S. H., and Hosseini, S. M. H. (2010). Effect of chitosan coatings enriched with cinnamon oil on the quality of refrigerated rainbow trout. Food Chem. 120, 193-198.

Otaibi, M. Al., and Demerdash, H. El. (2008). Improvement of the quality and shelf concentrated yoghurt (labneh) by the addition essential oils. Afr. J. Microbiol. Res. 2, 156-161.

Park, S. H., Choi, M. R., Park, J. W., Park, K. H., Chung, M. S., Ryu, S., and Kang, D. H. (2011). Use of organic acids to inactivate Escherichia coli O157, H7, Salmonella typhimurium, and Listeria monocytogenes on organic fresh apples and lettuce. J. Food Sci. 76, 293-298.

Pinto, M. S., Fernandes de Carvalho, A., Pires, A. C. S., Campos Souza, A. A., Fonseca da Silva, P. H., Sobral, D., de Paula, J. C. J., and de lima Santos, A. (2011). The effects of nisin on Staphylococcus aureus count and the physicochemical properties of Traditional Minas Serro cheese. Int. Dairy J. 21, 90-96.

Pires, A. C. S., Soares, N. F. F., Andrade, N. J., Silva, L. H. M., Camilloto, G. P., and Bernardes, P. C. (2009). Increased preservation of sliced mozzarella cheese by antimicrobial sachet incorporated with allyl isothiocyanate. $\mathrm{Braz}$. J. Microbiol. 40, 1002-1008.

Pyrgotou, N., Giatrakou, V., Ntzimani, A., and Savvaidis, I. N. (2010). Quality assessment of salted, modified atmosphere packaged rainbow trout under treatment with oregano essential oil. J. Food Sci. 75, 406-411.

Raybaudi-Massilia, R. M., MosquedaMelgar, J., and Martín-Belloso, O. (2008). Edible alginate-based coating as carrier of antimicrobials to improve shelf-life and safety of fresh-cut melon. Int. J. Food Microbiol. 121, 313-327.

Raybaudi-Massilia, R. M., MosquedaMelgar, J., Sobrino-Lòpez, A., Soliva-Fortuny, R., and MartínBelloso, O. (2009). Use of malic acid and other quality stabilizing compounds to assure the safety of fresh-cut "Fuji" apples by inactivation of Listeria Monocytogenes, Salmonella Enteritidis and Escherichia coli O157, H7. J. Food Saf. 29, 236-252.

Rehman, S., Hussain, S., and Nawaz, H. (2007). Inhibitory effect of citrus peel essential oils on the microbial growth of bread. Pak. J. Nut. 6 , 558-561.

Ricke, S. C. (2003). Perspectives on the use of organic acid and short chain fatty acid as antimicrobials. Poult. Sci. 82, 632-639.

Rojas-Graü, M. A., Raybaudi-Massilia, R. M., Soliva-Fortuny, R. C., AvenaBustillos, R. J., McHugh, T. H. and Martín-Belloso, O. (2007) Apple puree-alginate edible coating as carrier of antimicrobial agents to prolong shelf-life of fresh-cut apples. Postharvest Biol. Tec. 45, 254-264.

Rosyid, T. A., Karim, R., Adzahan, N. M., and Ghazali, F. M. (2011). Antibacterial activity of several Malaysian leaves extracts on the spoilage bacteria of yellow alkaline noodles. Afr. J. Microbiol. Res. 5, 898-904.

Ruiz-Cruz, S., Alvarez-Parrilla, E., de la Rosa, L. A., MartinezGonzalez, A. I., Ornelas-Paz, J., Mendoza-Wilson, A. M., and Gonzalez-Aguilar, G. A. (2010). Effect of different sanitizers on microbial, sensory and nutritional quality of fresh-cut jalapeno peppers. J. Agricul. Biol. Sci. 5, 331-341.

Rydlo, T., Miltz, J., and Mor, A. (2006). Eukaryotic antimicrobial peptides: promises and premises in food safety. J. Food Sci. 71, 125-135.

Sangsuwan, J., Rattanapanone, N., and Rachtanapun, P. (2008). Effect of chitosan/methyl cellulose films on microbial and quality characteristics of fresh-cut cantaloupe and pineapple. Postharv. Biol. Technol. 49, 403-410.

Selim, S. (2011). Antimicrobial activity of essential oils against Vancomycin-resistant enterococchi (VRE) and Escherichia Coli O157, $\mathrm{H} 7$ in feta soft cheese and minced beef meat. Braz. J. Microbiol. 42, 187-196.

Settanni, L., Franciosi, E., Cavazza, A. Cocconcelli, P. S., and Poznanski, E. (2011). Extension of Tosèla cheese shelf-life using non-starter lactic acid bacteria. Food Microbiol. 28 883-890.

Shelef, L., and Seiter, J. (1993). "Indirect antimicrobials," in Antimicrobials in Food, 2nd Edn. eds P. M. Davidson and A. L. Braner (New York, NY: Marcel Dekker), 544-555.

Shirazinejad, A. R., Noryati, I., Rosma, A., and Darah, I. (2010). Inhibitory Effect of Lactic Acid and Nisin on Bacterial Spoilage of Chilled Shrimp. World Acad. Sci. Eng. Technol. 65, 163-167.

Simões, A. D. N., Tudela, J. A., Allende, A., Puschmann, R., and Gil, M. I. (2009). Edible coatings containing chitosan and moderate modified atmospheres maintain quality and enhance phytochemicals of carrot sticks. Postharvest Biol. Technol. 51, 364-370.

Singh, G., Kapoor, I. P. S., and Singh, P. (2011). Effect of volatile oil and oleoresin of anise on the shelf life of yogurt. J. Food Process. Preserv. 35, 778-783.

Singh, T. K., Drake, M. A., and Cadwallader, K. R. (2003). Flavour of Cheddar cheese: a chemical and sensory perspective. Comp. Rev. Food Sci. Food Saf. 2, 139-162.

Sinigaglia, M., Bevilacqua, A., Corbo, M. R., Pati, S., and Del Nobile, M. A. (2008). Use of active compounds for prolonging the shelf life of mozzarella cheese. Int. Dairy J. $18,624-630$.

Skandamis, P., Tsigarida, E., and Nychas, G.-J. E. (2002). The effect of oregano essential oil on survival/death of Salmonella typhimurium in meat stored at $5^{\circ} \mathrm{C}$ under aerobic, VP/MAP conditions. Food Microbiol. 19, 97-103. 
Sobrino-Lopez, A., and MartinBelloso, O. (2006). Enhancing inactivation of Staphylococcus aureus in skim milk by combining high-intensity pulsed electric fields and nisin. J. Food Prot. 69, 345-353.

Soultos, N., Tzikas, Z., Abrahim, A., Georgantelis, D., and Ambrosiadis, I. (2008). Chitosan effects on quality properties of Greek style fresh pork sausages. Meat Sci. 80, 1150-1156.

Suhur, K. I., and Nielsen, P. V. (2005). Inhibition of fungal growth on wheat and rye bread by modified atmosphere packaging and active packaging using volatile mustard essential oil. Inst. Food Technol. 70, 37-44.

Theron, M. M., Lures, J., and Rykers, F. (2010). "Application of organic acid in food preservation" in Organic Acids and Food Preservation, eds Taylor and Francis Group (Boca Raton, FL: CRC Press), 51-95.

Tserennadmid, R., Takó, M., Galgóczy, L., Papp, T., Pesti, M., Vágvölgyi,
C., Almássy, K., and Krisch, J. (2011). Anti yeast activities of some essential oils in growth medium, fruit juices and milk. Int. J. Food Microbiol. 144, 480-486.

Ture, H., Eroglu, E., Ozen, B., and Soyer, F. (2011). Effect of biopolymers containing natamycin against Aspergillus niger and Penicillium roquefortii on fresh kashar cheese. Int. J. Food Sci. Technol. 46, 154-160.

Uçak, I., Özogul, Y., and Durmus, M. (2011). The effects of rosemary extract combination with vacuum packing on the quality changes of Atlantic mackerel fish burgers. Int. J. Food Sci. Technol. 46, 1157-1163.

Vaara, M. (1992). Agents that increase the permeability of the outer membrane. Microbiol. Rev. 56, 395-411.

Valero, M., and Salmerón, M. C. (2003). Antibacterial activity of 11 essential oils against Bacillus cereus in tyndallized carrot broth. Int. J. Food Microbiol. 85, 73-81.
Viuda-Martos, M., Ruiz-Navajas, Y., Fernandez-Lopez, J., and PerezAlvarez, J. A. (2010). Effect of added citrus fibre and spice essential oils on quality characteristics and shelflife of mortadella. Meat Sci. 85, 568-576.

Viuda-Martos, M., Ruiz-Navajas, Y., Fernández-López, J., and PérezÁlvarez, J. A. (2011). Effect of packaging conditions on shelf-life of Mortadella made with citrus fibre washing water and thyme or rosemary essential oil. Food Nutr. Sci. 2, 1-10.

Yasin, N. M. N., and Abou-Taleb, M. (2007). Antioxidant and antimicrobial effects of marjoram and thyme in coated refrigerated semi fried mullet fish fillets. World J. Dairy Food Sci. 2, 1-9.

Conflict of Interest Statement: The authors declare that the research was conducted in the absence of any commercial or financial relationships that could be construed as a potential conflict of interest.

Received: 26 April 2012; paper pending published: 21 May 2012; accepted: 21 July 2012; published online: 08 August 2012.

Citation: Lucera A, Costa C, Conte A and Del Nobile MA (2012) Food applications of natural antimicrobial compounds. Front. Microbio. 3:287. doi: 10.3389/fmicb.2012.00287

This article was submitted to Frontiers in Antimicrobials, Resistance and Chemotherapy, a specialty of Frontiers in Microbiology.

Copyright (๑) 2012 Lucera, Costa, Conte and Del Nobile. This is an openaccess article distributed under the terms of the Creative Commons Attribution License, which permits use, distribution and reproduction in other forums, provided the original authors and source are credited and subject to any copyright notices concerning any third-party graphics etc. 